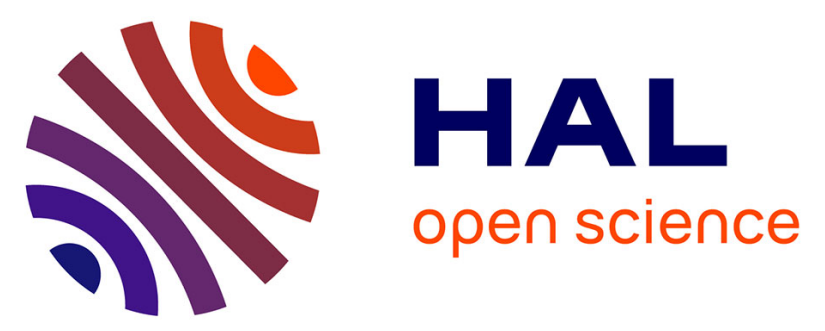

\title{
The effect of temperature onto the crystal structure of thioantimonates: solvothermal syntheses and crystal structures of $[\mathrm{Co}($ dien $) 2][\mathrm{Co}($ tren $) \mathrm{SbS} 4] 20.5 \mathrm{H} 2 \mathrm{O}$ and $[\mathrm{Co}($ tren $)] 2[\mathrm{CoSb} 2 \mathrm{~S} 6] \mathrm{H} 2 \mathrm{O}$
}

\author{
Wolfgang Bensch, Jessica Lichte, Henning Lühmann, Christian Näther
}

\section{To cite this version:}

Wolfgang Bensch, Jessica Lichte, Henning Lühmann, Christian Näther. The effect of temperature onto the crystal structure of thioantimonates: solvothermal syntheses and crystal structures of $[\mathrm{Co}$ (dien)2][Co(tren)SbS4]2 $0.5 \mathrm{H} 2 \mathrm{O}$ and [Co(tren)]2[CoSb2S6] H2O. Journal of Inorganic and General Chemistry / Zeitschrift für anorganische und allgemeine Chemie, 2009, 635 (12), pp.2021. 10.1002/zaac.200900177 . hal-00504927

\section{HAL Id: hal-00504927 \\ https://hal.science/hal-00504927}

Submitted on 22 Jul 2010

HAL is a multi-disciplinary open access archive for the deposit and dissemination of scientific research documents, whether they are published or not. The documents may come from teaching and research institutions in France or abroad, or from public or private research centers.
L'archive ouverte pluridisciplinaire HAL, est destinée au dépôt et à la diffusion de documents scientifiques de niveau recherche, publiés ou non, émanant des établissements d'enseignement et de recherche français ou étrangers, des laboratoires publics ou privés. 


\section{The effect of temperature onto the crystal structure of thioantimonates: solvothermal syntheses and crystal structures of [Co(dien)2][Co(tren)SbS4]2.0.5 H2O and $\{[\mathrm{Co}($ tren $)] 2[\mathrm{CoSb2S6}]\} \cdot \mathrm{H} 2 \mathrm{O}$}

\begin{tabular}{|r|l|}
\hline Journal: & Zeitschrift für Anorganische und Allgemeine Chemie \\
\hline Manuscript ID: & zaac.200900177.R1 \\
\hline Wiley - Manuscript type: & Article \\
\hline Author: & 02-Jun-2009 \\
\hline Complete List of Authors: & $\begin{array}{l}\text { Bensch, Wolfgang; Universitaet zu Kiel, Institut fuer Anorganische } \\
\text { Chemie } \\
\text { Lichte, Jessica; Universitaet zu Kiel, Institut für Anorganische } \\
\text { CHemie } \\
\text { Lühmann, Henning; Universitaet zu Kiel, Institut für Anorganische } \\
\text { CHemie } \\
\text { Näther, Christian; Universitaet zu Kiel, Institut für Anorganische } \\
\text { CHemie }\end{array}$ \\
\hline Keywords: & Solvothermal Synthesis, Thioantimonates, Crystal Structure \\
\hline &
\end{tabular}

\section{S ScholarONE" \\ Manuscript Central}




\title{
ARTICLE
}

DOI: 10.1002/zaac.200((will be filled in by the editorial staff))

\section{The effect of temperature onto the crystal structure of thioantimonates: solvothermal syntheses and crystal structures of $\left[\mathrm{Co}(\text { dien })_{2}\right]\left[\mathrm{Co}(\operatorname{tren}) \mathrm{SbS}_{4}\right]_{2} \cdot \mathrm{0.5} \mathrm{H}_{2} \mathrm{O}$ and $\left\{[\mathrm{Co}(\text { tren })]_{2}\left[\mathrm{CoSb}_{2} \mathrm{~S}_{6}\right]\right\} \cdot \mathrm{H}_{2} \mathrm{O}$}

\author{
Jessica Lichte, Henning Lühmann, Christian Näther and Wolfgang Bensch ${ }^{[*]}$ \\ Institut für Anorganische Chemie, Christian-Albrechts-Universität zu Kiel
}

Dedicated to Prof. Dr. Martin Jansen on the occasion of his 65th birthday 巨

Keywords: Solvothermal Synthesis, Thioantimonates, Crystal Structure

[*] Prof. Dr. W. Bensch, Institut für Anorganische Chemie der Universität Kiel, Max-Eyth-Str. 2, D-24118 Kiel Fax: +49 (0)431/880 -1520,

e-Mail: wbensch@ac.uni-kiel.de

\section{Introduction}

In the past few years we and other groups demonstrated that a large variety of amines are suitable structure directing molecules for the preparation of thioantimonates under solvothermal conditions [1-24]. A challenge in the field of thioantimonate chemistry is the integration of transition metal ions into the thioantimonate networks. Using mono-, bi- or tridentate amine molecules like methylamine, ethylenediamine or diethylenetriamine (dien) mainly transition metal complexes are formed which are separated from the anionic network [25-38]. Exceptions are the chalcophilic cations $\mathrm{Cu}^{+}$and $\mathrm{Ag}^{+}$which easily form bonds to the $\mathrm{S}$ atoms of thioantimonate anions [39-45]. An interesting behavior is also observed for $\mathrm{Mn}^{2+}$ which seems to have a comparable affinity to $\mathrm{N}$ and $\mathrm{S}$. Hence, many $\mathrm{Mn}^{2+}$ thioantimonates were synthesized even applying typical complex forming amines [46-53]. The integration of transition metal cations can be forced using special multidentate amines like tris(2-aminoethyl)amine (tren). This tetradentate amine saturates only four coordination sites of transition metal cations $\left(\mathrm{TM}^{\mathrm{n}+}\right)$ like $\mathrm{Cr}^{3+}, \mathrm{Mn}^{2+}, \mathrm{Co}^{2+}$,
$\mathrm{Ni}^{2+}, \mathrm{Fe}^{2+}$ or $\mathrm{Zn}^{2+}$ [54-62] opening the possibility of bond formation between the chelated $\mathrm{TM}^{\mathrm{n}+}$ and the thioantimonate network. On the other hand the advantage of isolated $\left[\mathrm{TM}(\text { amine })_{\mathrm{x}}\right]^{\mathrm{n}+}$ complexes is their large size and often thioantimonates are formed being characterized by large rings or cavities [27, 34, 35]. A new approach in the field of thioantimonate chemistry is to combine isolated $\left[\mathrm{TM}(\text { amine })_{\mathrm{x}}\right]^{\mathrm{n}+}$ complexes as space fillers and charge compensating ions with coordinatively unsaturated complexes bonded to the network. The final goal is the synthesis of structural architectures containing large pores or tunnels due to the presence of the complexes and a thioantimonate network with integrated $\mathrm{TM}^{\mathrm{n}+}$ cations. Very recently we reported the synthesis and structure of $\left[\mathrm{Co}(\text { dien })_{2}\right]\left[\mathrm{Co} \text { (tren) } \mathrm{SbS}_{4}\right]_{2} \cdot 4 \mathrm{H}_{2} \mathrm{O}$ [63] which contains isolated $\left[\mathrm{Co}(\text { dien })_{2}\right]^{2+}$ and $\left[\mathrm{Co}(\text { tren }) \mathrm{SbS}_{4}\right]^{-}$complexes. The compound represents one of the few samples of a thioantimonate $(\mathrm{V})$ with the $\left[\mathrm{SbS}_{4}\right]^{3-}$ anion being bonded to a $\mathrm{TM}^{\mathrm{n}+}$ cation. We further explored the system Co-Sb-S-dientren by changing the dien:tren ratio and varying the temperature. In the paper we present the crystal structures of two new thioantimonates, namely $\left[\mathrm{Co}(\text { dien })_{2}\right][\mathrm{Co}$ (tren $\left.) \mathrm{SbS}_{4}\right]_{2} \cdot 0.5 \mathrm{H}_{2} \mathrm{O}(\mathbf{1})$ which is a pseudopolymorph to $\left[\mathrm{Co}(\text { dien })_{2}\right][\mathrm{Co}$ (tren $\left.) \mathrm{SbS}_{4}\right]_{2} \cdot 4 \mathrm{H}_{2} \mathrm{O}$ and $\left\{[\mathrm{Co}(\text { tren })]_{2}\left[\mathrm{CoSb}_{2} \mathrm{~S}_{6}\right]\right\} \cdot \mathrm{H}_{2} \mathrm{O}(2)$. A new structural feature of 2 is the heterometallic $\left[\mathrm{CoSb}_{2} \mathrm{~S}_{6}\right]^{4-}$ core which was not observed before. 


\section{Results and Discussion}

The two new compounds were obtained in a mixture of dien and tren applying the ratio dien:tren $=2.4: 0.6 \mathrm{~mL}$ in 1 $\mathrm{mL}$ water. Phase pure $\left[\mathrm{Co}(\text { dien })_{2}\right]\left[\mathrm{Co} \text { (tren) } \mathrm{SbS}_{4}\right]_{2} \cdot 0.5 \mathrm{H}_{2} \mathrm{O}$ is formed exclusively at $110{ }^{\circ} \mathrm{C}$ whereas mixtures of both compounds were observed at 120 and $130{ }^{\circ} \mathrm{C}$. A series of experiments was performed at 120 and $130{ }^{\circ} \mathrm{C}$ varying the reaction time between 3 and $6 \mathrm{~d}$. But in all products a mixture of the two title compounds was obtained. Variation of the ratio of the amines $\left(\mathrm{T}=120\right.$ and $130{ }^{\circ} \mathrm{C}$, dien:tren $=$ 2.7:0.3, 2.6:0.4 and 2.5:0.5 with $1 \mathrm{~mL} \mathrm{H}_{2} \mathrm{O}$ ) and also the absolute amount of the amine in $1 \mathrm{~mL}$ water (dien:tren: 1.3:0.2 - 1.8:0.3) resulted in mixtures of the two compounds After increasing the temperature above $130{ }^{\circ} \mathrm{C}$ only an unknown polycrystalline compound is obtained. We note that the pseudo-polymorphic compound $\left[\mathrm{Co}(\text { dien })_{2}\right]\left[\mathrm{Co} \text { (tren) } \mathrm{SbS}_{4}\right]_{2} \cdot 4 \mathrm{H}_{2} \mathrm{O}$ [63] was synthesized at $140{ }^{\circ} \mathrm{C}$ in a mixture of $2 \mathrm{~mL} \mathrm{50 \%} \mathrm{tren} \mathrm{and} 1 \mathrm{~mL} \mathrm{50 \%} \mathrm{dien,}$ i.e. the amine solution was more diluted than that used for the synthesis of compound $\mathbf{1}$. At the lower reaction temperature compound $\mathbf{1}$ is formed containing the $\left[\mathrm{Sb}(\mathrm{V}) \mathrm{S}_{4}\right]^{3-}$ anion whereas $\left[\mathrm{Sb}(\mathrm{III}) \mathrm{S}_{3}\right]^{3-}$ units are observed in compound 2. A more diluted amine mixture and a higher reaction temperature afforded the formation of $\left[\mathrm{Co}(\text { dien })_{2}\right]\left[\mathrm{Co} \text { (tren) } \mathrm{SbS}_{4}\right]_{2} \cdot 4 \mathrm{H}_{2} \mathrm{O}$ which also contains the $\mathrm{Sb}(\mathrm{V})$ species. The analysis of the synthesis conditions where the $\left[\mathrm{Sb}(\mathrm{V}) \mathrm{S}_{4}\right]^{3-}$ species was obtained give no clear rules concerning the reaction temperature and amine concentration. For instance, $[\mathrm{Mn}($ tren $)$ trenH) $] \mathrm{SbS}_{4}$ was obtained at $140{ }^{\circ} \mathrm{C}$ applying a concentrated tren solution [60]. On the other hand $\left[\mathrm{Mn}(\operatorname{chxn})_{3}\right]_{2}\left[\mathrm{Mn}(\operatorname{chxn})_{2}\left(\mathrm{SbS}_{4}\right)_{2}\right] \cdot 6 \mathrm{H}_{2} \mathrm{O}$ crystallized in $50 \%$ 1,2-diaminocyclohexane (chxn) solution [61]. In several cases we obtained $\left[\mathrm{Sb}(\mathrm{III}) \mathrm{S}_{3}\right]^{3-}$ containing compounds like $[\mathrm{Ni}$ (tren) $] \mathrm{Sb}_{2} \mathrm{~S}_{4}, \quad[\mathrm{Co}$ (tren) $] \mathrm{Sb}_{2} \mathrm{~S}_{4}$ [55] in diluted tren or $[\mathrm{Co} \text { (tren) }]_{2} \mathrm{Sb}_{4} \mathrm{~S}_{8}$ resp. $[\mathrm{Co} \text { (tren) }]_{2} \mathrm{Sb}_{2} \mathrm{~S}_{5}$ in concentrated tren solution [54]. Summarizing shortly there are no rules at hand for the prediction whether the reaction product contains $\mathrm{Sb}(\mathrm{III})$ or $\mathrm{Sb}(\mathrm{V})$ species.

Compound $\mathbf{1}$ crystallizes in the monoclinic space group $C 2 / c$ (Table 1) with all atoms except $\mathrm{Co}(2)$ being located on general positions. The structure is composed of isolated $\left[\mathrm{Co}(2)(\text { dien })_{2}\right]^{2+}$ and $\left[\mathrm{Co}(1)(\text { tren }) \mathrm{SbS}_{4}\right]^{-}$complexes and $1 / 2$ $\mathrm{H}_{2} \mathrm{O}$ (Fig. 1). The $\mathrm{Co}(2)^{2+}$ cation is octahedrally surrounded by two tridentate dien ligands in the $s$-fac-configuration. The Co(2)-N bond lengths between 2.153(4) and 2.192(5) $\AA$ are in the range found in other Co amine compound [54-56]. The angles around $\mathrm{Co}(2)^{2+}$ (Table 2) indicate a moderate distortion of the $\mathrm{CoN}_{6}$ octahedron. In the anionic complex $\left[\mathrm{Co}(1)(\text { tren }) \mathrm{SbS}_{4}\right]^{-}$the $\mathrm{Co}(1)^{2+}$ cation is in a trigonal bipyramidal geometry of four $\mathrm{N}$ atoms of the tren ligand and one $\mathrm{S}$ atom of the $\left[\mathrm{SbS}_{4}\right]^{3-}$ anion (Fig. 1). Like in the pseudo-polymorph the $\mathrm{Co}(1)-\mathrm{N}$ bond in trans position to the $\mathrm{Co}(1)-\mathrm{S}(1)$ bond is longer $(2.247(3) \AA)$ than the remaining Co(1)-N bonds $(2.072(3)-2.083(2) \AA$; Table 1). Such an elongation of a bond can be explained with the so-called trans-effect. The $\operatorname{Co}(1)-\mathrm{S}(1)$ bond at 2.3701(8) $\AA$ is in the range of data published in literature $[54,55]$. The angles around the $\operatorname{Co}(1)^{2+}$ cation suggest an appreciable distortion (Table 2). The Sb-S bond lengths and $\mathrm{S}-\mathrm{Sb}-\mathrm{S}$ angles are typical for a moderately distorted $\left[\mathrm{Sb}(\mathrm{V}) \mathrm{S}_{4}\right]^{3-}$ tetrahedron. The arrangement of the cations and anions in the unit cell is very similar to that observed for the pseudo-polymorphic compound.

Figure 1. The $\left[\mathrm{Co}(1)(\operatorname{tren}) \mathrm{SbS}_{4}\right]^{-}$(left) and the $\left[\mathrm{Co}(2)(\mathrm{dien})_{2}\right]^{2+}$ (right) complexes in compound $\mathbf{1}$. Not all atoms are labeled.

Table 1. Selected technical details of data collection and results of the structure refinement of the title compounds.

\begin{tabular}{|c|c|c|}
\hline & 1 & $\stackrel{2}{2}$ \\
\hline formula & $\mathrm{C}_{20} \mathrm{H}_{64} \mathrm{Co}_{3} \mathrm{~N}_{14} \mathrm{OS}_{8} \mathrm{Sb}_{2}$ & $\mathrm{C}_{12} \mathrm{H}_{38} \mathrm{Co}_{3} \mathrm{~N}_{8} \mathrm{OS}_{6} \mathrm{Sb}_{2}$ \\
\hline $\mathrm{MW} / \mathrm{g} \mathrm{mol}^{-1}$ & 1193.62 & 923.15 \\
\hline crystal system & monoclinic & monoclinic \\
\hline space group & $C 2 / c$ & $P 2_{1} / c$ \\
\hline$a / \AA$ & $29.378(3)$ & $13.870(2)$ \\
\hline$b / \AA$ & $7.6643(4)$ & $14.708(1)$ \\
\hline$c / \AA$ & $22.507(2)$ & $14.700(2)$ \\
\hline$\beta / \operatorname{deg}$ & $115.39(1)$ & $94.62(2)$ \\
\hline$V / \AA^{3}$ & $4578.3(7)$ & $2989.0(4)$ \\
\hline$T / \mathrm{K}$ & 293 & 170 \\
\hline$Z$ & 4 & 4 \\
\hline$D_{\text {calc }} / \mathrm{g} \mathrm{cm}^{-3}$ & 1.732 & 2.105 \\
\hline$\mu / \mathrm{mm}^{-1}$ & 2.630 & 3.856 \\
\hline $\min / \max$ transm. & $0.629 / 0.732$ & $0.0340 / 0.633$ \\
\hline$\theta_{\max } / \operatorname{deg}$ & 28.06 & 27.97 \\
\hline No. refl. & 25442 & 30651 \\
\hline$R_{\text {int }}$ & 0.0375 & 0.0583 \\
\hline unique refl. & 5490 & 7162 \\
\hline $\begin{array}{l}\text { Refl. }\left[\mathrm{F}_{0}>\right. \\
\left.4 \sigma\left(\mathrm{F}_{0}\right)\right]\end{array}$ & 4678 & 6159 \\
\hline parameter & 242 & 290 \\
\hline $\begin{array}{l}R_{1}^{[\mathrm{a}]}\left[\mathrm{F}_{0}>\right. \\
\left.4 \sigma\left(\mathrm{F}_{0}\right)\right]\end{array}$ & 0.0345 & 0.0289 \\
\hline$w R_{2}{ }^{[b]}$ [all data] & 0.0949 & 0.0724 \\
\hline GOF & 1.019 & 1.0002 \\
\hline $\begin{array}{l}\Delta \rho_{\max }, \Delta \rho_{\min } / \mathrm{e} \\
\AA^{-3}\end{array}$ & $0.808,-0.840$ & $0.777,-1.284$ \\
\hline
\end{tabular}

[a] $\mathrm{R}_{1}=\sum\left\|\mathrm{F}_{0}|-| \mathrm{F}_{\mathrm{c}}\right\| / \sum\left|\mathrm{F}_{0}\right| .[\mathrm{b}] \mathrm{wR}_{2}=\left[\sum\left[\mathrm{w}\left(\mathrm{F}_{0}{ }^{2}-\mathrm{F}_{\mathrm{c}}\right)^{2}\right] / \sum\left[\mathrm{w}\left(\mathrm{F}_{0}{ }^{2}\right)^{2}\right]\right]^{1 / 2}$.

The anions are grouped in pairs and form rods along [010] and [001]. The cations are arranged in a similar way with the difference that $\left[\mathrm{Co}(2)(\text { dien })_{2}\right]^{2+}$ complexes and water molecules alternate along [001]. The main difference to the pseudo-polymorphic compound $\left[\mathrm{Co}(\text { dien })_{2}\right][\mathrm{Co}$ (tren $\left.) \mathrm{SbS}_{4}\right]_{2} \cdot 4 \mathrm{H}_{2} \mathrm{O} \quad$ [63] is the hydrogen bonding pattern between the different constituents. An extended H-bonding network was observed in $\left[\mathrm{Co}(\text { dien })_{2}\right][\mathrm{Co}$ (tren $\left.) \mathrm{SbS}_{4}\right]_{2} \cdot 4 \mathrm{H}_{2} \mathrm{O}$ involving $\mathrm{N}, \mathrm{S}$ and $\mathrm{O}$ atoms. Due to the lower water content in 1 the $\mathrm{H}$-bonding interactions are less complex.

Fig. 2: Packing of the $\left[\mathrm{Co}(1)(\text { tren }) \mathrm{SbS}_{4}\right]^{-}$and the $\left[\mathrm{Co}(2)(\operatorname{dien})_{2}\right]^{2+}$ complexes in compound $\mathbf{1}$ with view along [010].

Table 2. Selected bond lengths $(\AA)$ and angles $\left(^{\circ}\right)$ for compound $\mathbf{1}$. Estimated standard deviations are given in parentheses. 


$\begin{array}{lc}\mathrm{Sb}(1)-\mathrm{S}(3) & 2.3078(10) \\ \mathrm{Sb}(1)-\mathrm{S}(2) & 2.3189(9) \\ \mathrm{Sb}(1)-\mathrm{S}(4) & 2.3196(11) \\ \mathrm{Sb}(1)-\mathrm{S}(1) & 2.3701(8) \\ \mathrm{Co}(1)-\mathrm{S}(1) & 2.3637(9) \\ \mathrm{Co}(1)-\mathrm{N}(1) & 2.247(3) \\ \mathrm{Co}(1)-\mathrm{N}(2) & 2.072(3) \\ \mathrm{Co}(1)-\mathrm{N}(3) & 2.079(3) \\ \mathrm{Co}(1)-\mathrm{N}(4) & 2.083(2) \\ \mathrm{S}(3)-\mathrm{Sb}(1)-\mathrm{S}(1) & 106.24(4) \\ \mathrm{S}(2)-\mathrm{Sb}(1)-\mathrm{S}(1) & 110.77(3) \\ \mathrm{S}(4)-\mathrm{Sb}(1)-\mathrm{S}(1) & 110.04(4) \\ \mathrm{S}(3)-\mathrm{Sb}(1)-\mathrm{S}(2) & 110.04(4) \\ \mathrm{S}(3)-\mathrm{Sb}(1)-\mathrm{S}(4) & 113.30(5) \\ \mathrm{S}(2)-\mathrm{Sb}(1)-\mathrm{S}(4) & 106.50(4) \\ \mathrm{Co}(1)-\mathrm{S}(1)-\mathrm{Sb}(1) & 104.50(3) \\ \mathrm{N}(4)-\mathrm{Co}(1)-\mathrm{N}(1) & 79.30(10) \\ \mathrm{N}(2)-\mathrm{Co}(1)-\mathrm{S}(1) & 101.67(8) \\ \mathrm{N}(3)-\mathrm{Co}(1)-\mathrm{S}(1) & 100.81(8) \\ \mathrm{N}(4)-\mathrm{Co}(1)-\mathrm{S}(1) & 98.92(7) \\ \mathrm{N}(1)-\mathrm{Co}(1)-\mathrm{S}(1) & 178.19(8) \\ \mathrm{N}(2)-\mathrm{Co}(1)-\mathrm{N}(3) & 113.18(13) \\ \mathrm{N}(2)-\mathrm{Co}(1)-\mathrm{N}(4) & 120.52(12) \\ \mathrm{N}(3)-\mathrm{Co}(1)-\mathrm{N}(4) & 116.63(11) \\ \mathrm{N}(2)-\mathrm{Co}(1)-\mathrm{N}(1) & 79.62(11) \\ \mathrm{N}(3)-\mathrm{Co}(1)-\mathrm{N}(1) & 79.76(11) \\ \mathrm{Co}(2)-\mathrm{N}(11) & 2.192(5) \\ \mathrm{Co}(2)-\mathrm{N}(12) & 2.153(4) \\ \mathrm{Co}(2)-\mathrm{N}(13) & 2.180(4) \\ \mathrm{N}(12)-\mathrm{Co}(2)-\mathrm{N}(13) & 98.97(15) \\ \mathrm{N}(12)-\mathrm{Co}(2)-\mathrm{N}(13) & 98.59(12) \\ \mathrm{N}(12)-\mathrm{Co}(2)-\mathrm{N}(11) & 89.54(11) \\ \mathrm{N}(12)-\mathrm{Co}(2)-\mathrm{N}(11) & \\ \mathrm{N}(13)-\mathrm{Co}(2)-\mathrm{N}(11) & \\ \mathrm{N}(13)-\mathrm{Co}(2)-\mathrm{N}(11) & \\ & \\ & \\ & \end{array}$

The shortest $\mathrm{O} \cdots \mathrm{O}, \mathrm{O} \cdots \mathrm{S}$ and $\mathrm{O} \cdots \mathrm{N}$ separations are 3.054, 3.471 and $3.722 \AA$ respectively which are all significantly longer than in $\left[\mathrm{Co}(\text { dien })_{2}\right]\left[\mathrm{Co}(\text { tren }) \mathrm{SbS}_{4}\right]_{2} \cdot 4 \mathrm{H}_{2} \mathrm{O}$ and too long for significant $\mathrm{H}$-bonding interactions. Nevertheless, the $\mathrm{S}$ atoms join neighbored cations and anions to form layers in he (001) plane (see Table 3 ).

Table 3: Geometric parameters $\left[\AA{ }^{\circ}{ }^{\circ}\right.$ ] of the hydrogen bonds in compound 1.

\begin{tabular}{lrr}
\hline D-H & d(H..A) & $<$ DHA \\
\hline N2-H1N & 2.565 & 151.25 \\
N2-H2N & 2.595 & 155.87 \\
N3-H3N & 2.824 & 140.19 \\
N3-H4N & 2.562 & 147.45 \\
N4-H5N & 2.663 & 135.23 \\
N4-H6N & 2.600 & 162.17 \\
N11-H7N & 2.580 & 148.25 \\
N11-H8N & 2.897 & 141.83 \\
N12-H9N & 2.638 & 148.26 \\
N13-H10N & 2.818 & 159.38 \\
N13-H11N & 2.578 & 167.59 \\
\hline
\end{tabular}

d(D..A)
3.382
3.436
3.563
3.356
3.362
3.468
3.379
3.647
3.436
3.674
3.462

A $\mathrm{S} 2$ $\mathrm{S} 1$ $\mathrm{S} 2$ $\mathrm{S} 1$ S2 $\mathrm{S} 4$ S4 S3 S2 $\mathrm{S} 2$ S4

The second new compound $\left\{[\mathrm{Co}(\text { tren })]_{2}\left[\mathrm{CoSb}_{2} \mathrm{~S}_{6}\right]\right\} \cdot \mathrm{H}_{2} \mathrm{O}$ (2) crystallizes in the monoclinic spaces group $P 2_{1} / c$ (Table
1) with all atoms being located on general positions. The structure may be viewed as consisting of a central $\left[\mathrm{CoSb}_{2} \mathrm{~S}_{6}\right]^{4-}$ core acting as a bidentate ligand to two independent $\left[\mathrm{Co}(\text { tren) }]^{2+}\right.$ complexes (Fig. 3). Alternatively one may describe the structure as two independent $\left[\mathrm{Co}(\text { tren }) \mathrm{SbS}_{3}\right]^{-}$complexes which are connected by a $\mathrm{Co}^{2+}$ cation. The $\mathrm{Co}(1)^{2+}$ and $\mathrm{Co}(3)^{2+}$ cations are each coordinated by four $\mathrm{N}$ atoms of the tren ligand and by one $\mathrm{S}$ atom of a $\left[\mathrm{SbS}_{3}\right]$ trigonal pyramid. Like in compound $\mathbf{1}$ the Co-N bonds in trans-position to the Co-S bond are longer than the remaining Co-N bonds (Table 4 ).

Fig. 3: Interconnection of the different constituents in the structure of $\left\{[\mathrm{Co} \text { (tren) }]_{2}\left[\mathrm{CoSb}_{2} \mathrm{~S}_{6}\right]\right\}(2)$. Note that not all atoms are labeled.

The Sb-S bond lengths are between 2.3927(8) and 2.4332(8) $\AA$ as well as the angles S-Sb-S are typical for the $\left[\mathrm{SbS}_{3}\right]^{3-}$ anion [1-20]. The central $\mathrm{Co}(2)^{2+}$ cation is in a strongly distorted tetrahedral environment of four $\mathrm{S}$ atoms of the two independent $\left[\mathrm{SbS}_{3}\right]$ moieties with $\mathrm{Co}(2)-\mathrm{S}$ bond lengths ranging from 3.452(8) to 2.3550(9) A (Table 4). The angles S-Co(2)-S scatter from 95.26(3) to $120.63(3)^{\circ}$ evidencing the severe distortion of the polyhedron. It can be assumed that the distortion is caused by the bulky $[\mathrm{Co}(\text { tren })]^{2+}$ complexes not allowing a more relaxed $\left[\mathrm{CoS}_{4}\right]$ tetrahedron. The bidentate binding mode of the $\left[\mathrm{SbS}_{3}\right]$ pyramids to the $\operatorname{Co}(2)^{2+}$ cation leads to relative acute angles around $S(2), S(3), S(5)$ and $S(6)$ of about $86^{\circ}$. The compact arrangement of the different building units also affects the two [Co(tren)] environments. The trans-angles N(1)-Co(1)$\mathrm{S}(1)$ and $\mathrm{N}(11)-\mathrm{Co}(3)-\mathrm{S}(6)$ deviate more from the ideal $180^{\circ}$ than in compound $\mathbf{1}$ (see Table 4 ).

Table 4. Selected bond lengths [Å] and angles [deg] for compound 2. Estimated standard deviations are given in parentheses.

$\begin{array}{lc}\mathrm{Sb}(1)-\mathrm{S}(1) & 2.4079(7) \\ \mathrm{Sb}(1)-\mathrm{S}(2) & 2.4161(8) \\ \mathrm{Sb}(1)-\mathrm{S}(3) & 2.4114(8) \\ \mathrm{Sb}(2)-\mathrm{S}(4) & 2.4298(8) \\ \mathrm{Sb}(2)-\mathrm{S}(5) & 2.4332(8) \\ \mathrm{Sb}(2)-\mathrm{S}(6) & 2.3927(8) \\ \mathrm{S}(1)-\mathrm{Sb}(1)-\mathrm{S}(3) & 103.02(3) \\ \mathrm{S}(1)-\mathrm{Sb}(1)-\mathrm{S}(2) & 105.98(3) \\ \mathrm{S}(3)-\mathrm{Sb}(1)-\mathrm{S}(2) & 91.83(3) \\ \mathrm{S}(6)-\mathrm{Sb}(2)-\mathrm{S}(4) & 105.98(3) \\ \mathrm{S}(6)-\mathrm{Sb}(2)-\mathrm{S}(5) & 104.69(3) \\ \mathrm{S}(4)-\mathrm{Sb}(2)-\mathrm{S}(5) & 91.48(3) \\ \mathrm{Co}(1)-\mathrm{N}(1) & 2.240(2) \\ \mathrm{Co}(1)-\mathrm{N}(2) & 2.086(3) \\ \mathrm{Co}(1)-\mathrm{N}(3) & 2.095(2) \\ \mathrm{Co}(1)-\mathrm{N}(4) & 2.070(3) \\ \mathrm{Co}(1)-\mathrm{S}(1) & 2.3500(9) \\ \mathrm{Co}(2)-\mathrm{S}(2) & 2.3452(8) \\ \mathrm{Co}(2)-\mathrm{S}(4) & 2.3398(8) \\ \mathrm{Co}(2)-\mathrm{S}(3) & 2.3484(9) \\ \mathrm{Co}(2)-\mathrm{S}(5) & 2.3594(9) \\ \mathrm{Co}(3)-\mathrm{N}(13) & 2.080(3) \\ \mathrm{Co}(3)-\mathrm{N}(12) & 2.096(2) \\ \mathrm{Co}(3)-\mathrm{N}(14) & 2.099(2)\end{array}$




\author{
$\mathrm{Co}(3)-\mathrm{N}(11)$ \\ Co(3)-S(6) \\ $\mathrm{N}(4)-\mathrm{Co}(1)-\mathrm{N}(2)$ \\ $\mathrm{N}(4)-\mathrm{Co}(1)-\mathrm{N}(3)$ \\ $\mathrm{N}(2)-\mathrm{Co}(1)-\mathrm{N}(3)$ \\ $\mathrm{N}(4)-\mathrm{Co}(1)-\mathrm{N}(1)$ \\ $\mathrm{N}(2)-\mathrm{Co}(1)-\mathrm{N}(1)$ \\ $\mathrm{N}(3)-\mathrm{Co}(1)-\mathrm{N}(1)$ \\ $\mathrm{N}(4)-\mathrm{Co}(1)-\mathrm{S}(1)$ \\ $\mathrm{N}(2)-\mathrm{Co}(1)-\mathrm{S}(1)$ \\ $\mathrm{N}(3)-\mathrm{Co}(1)-\mathrm{S}(1)$ \\ $\mathrm{N}(1)-\mathrm{Co}(1)-\mathrm{S}(1)$ \\ $\mathrm{S}(4)-\mathrm{Co}(2)-\mathrm{S}(2)$ \\ $\mathrm{S}(4)-\mathrm{Co}(2)-\mathrm{S}(3)$ \\ $\mathrm{S}(2)-\mathrm{Co}(2)-\mathrm{S}(3)$ \\ $\mathrm{S}(4)-\mathrm{Co}(2)-\mathrm{S}(5)$ \\ $\mathrm{S}(2)-\mathrm{Co}(2)-\mathrm{S}(5)$ \\ $\mathrm{S}(3)-\mathrm{Co}(2)-\mathrm{S}(5)$ \\ $\mathrm{N}(13)-\mathrm{Co}(3)-\mathrm{N}(12)$ \\ $\mathrm{N}(13)-\mathrm{Co}(3)-\mathrm{N}(14)$ \\ $\mathrm{N}(12)-\mathrm{Co}(3)-\mathrm{N}(14)$ \\ $\mathrm{N}(13)-\mathrm{Co}(3)-\mathrm{N}(11)$ \\ $\mathrm{N}(12)-\mathrm{Co}(3)-\mathrm{N}(11)$ \\ $\mathrm{N}(14)-\mathrm{Co}(3)-\mathrm{N}(11)$ \\ $\mathrm{N}(13)-\mathrm{Co}(3)-\mathrm{S}(6)$ \\ $\mathrm{N}(12)-\mathrm{Co}(3)-\mathrm{S}(6)$ \\ $\mathrm{N}(14)-\mathrm{Co}(3)-\mathrm{S}(6)$ \\ $\mathrm{N}(11)-\mathrm{Co}(3)-\mathrm{S}(6)$
}

The $\left\{[\mathrm{Co} \text { (tren) }]_{2}\left[\mathrm{CoSb}_{2} \mathrm{~S}_{6}\right]\right\}$ units are stacked along [1-10] to form rods with several intermolecular N-H..S interactions. We note that there are also some intramolecular $\mathrm{S} \cdots \mathrm{H}$ distances which indicate hydrogen bonding interactions. In addition the $\mathrm{S}(5)$ and $\mathrm{N}(3)$ atoms have such $\mathrm{H}$-bonding contacts to the $\mathrm{O}$ atom of the water molecule (Table 5).

Figure 4. Arrangement of $\left\{[\mathrm{Co}(\text { tren })]_{2}\left[\mathrm{CoSb}_{2} \mathrm{~S}_{6}\right]\right\}$ moieties and $\mathrm{H}_{2} \mathrm{O}$ molecules in compound 2 .

Table 5. Selected geometric parameters $\left[\AA{ }^{\circ}{ }^{\circ}\right]$ for the hydrogen bonds in compound $\mathbf{2}$.

\begin{tabular}{lcccc}
\hline D-H & d(H..A) & <DHA & d(D..A) & A \\
\cline { 1 - 2 } N2-H2N & 2.829 & 137.25 & 3.559 & S3 \\
N3-H3N & 2.70 & 145.84 & 3.500 & S2 \\
N3-H4N & 2.133 & 146.69 & 2.945 & O1 \\
N4-H5N & 2.494 & 160.80 & 3.376 & S2 \\
N4-H6N & 2.425 & 173.46 & 3.341 & S1 \\
N12-H7N & 2.724 & 145.24 & 3.519 & S1 \\
N12-H8N & 2.868 & 135.54 & 3.583 & S3 \\
N12-H8N & 2.877 & 136.97 & 3.605 & S5 \\
N13-H9N & 2.429 & 162.29 & 3.318 & S4 \\
N13-H10N & 2.725 & 144.28 & 3.513 & S6 \\
N14-H11N & 2.719 & 153.84 & 3.568 & S4 \\
N14-H12N & 2.594 & 169.28 & 3.502 & S3 \\
O1-H1O1 & 2.533 & 165.56 & 3.353 & S5 \\
O1-H2O1 & 2.544 & 170.02 & 3.374 & S5
\end{tabular}

\section{Conclusions}

Changing the synthesis conditions we were able to synthesize a pseudo-polymorph of the recently published compound $\quad\left[\mathrm{Co}(\text { dien })_{2}\right]\left[\mathrm{Co}(\text { tren }) \mathrm{SbS}_{4}\right]_{2} \cdot 4 \mathrm{H}_{2} \mathrm{O} \quad$ [63]. Compound $\mathbf{1}$ and the latter compound crystallize in different space groups which can be explained by the very different hydrogen bonding networks in the two structures. The geometric parameters in the two polymorphs are very similar and also the arrangement of the two different complexes is nearly identical. The second compound presents a new and hitherto never observed heterometallic $\left[\mathrm{CoSb}_{2} \mathrm{~S}_{6}\right]$ core as main structural feature. Until now such heterometallic building units were only observed for $\mathrm{Mn}^{2+}$ like in $[\mathrm{Mn}(\text { tren })]_{2}\left[\mathrm{Mn}_{2} \mathrm{Sb}_{4} \mathrm{~S}_{10}\right]$ where the $\left[\mathrm{Mn}_{2} \mathrm{Sb}_{4} \mathrm{~S}_{10}\right]$ core contains two edge-sharing $\left[\mathrm{MnS}_{4}\right]$ tetrahedra [58], or in $[\mathrm{Mn} \text { (tren) }]_{4} \mathrm{Mn}_{2} \mathrm{Sb}_{4} \mathrm{~S}_{12}$ where two $\left[\mathrm{MnS}_{4}\right]$ tetrahedra are joined by two $\left[\mathrm{SbS}_{3}\right]$ pyramids [61]. A further surprise is the fact that one $\mathrm{Co}^{2+}$ cation prefers a $\mathrm{S}^{2-}$ environment whereas the other two $\mathrm{Co}^{2+}$ ions are surrounded by $\mathrm{N}$ and $\mathrm{S}$ atoms. In the syntheses of compound 2 the amines supplied are in a large excess compared to sulfur. Hence we can exclude that a deficiency of ligand atoms is responsible for the formation of the $\left[\mathrm{CoS}_{4}\right]$ tetrahedral unit. The results of the present synthetic work encourage us to further explore the chemistry of thiometallates using amine mixtures.

\section{Experimental Section}

\section{Sample synthesis}

Both compounds were prepared applying $\mathrm{Co}, \mathrm{Sb}$ and $\mathrm{S}$ in the 1:1:3 mmol ratio. A mixture of $0.4 \mathrm{~mL}$ tren, $2.6 \mathrm{~mL}$ dien and $1 \mathrm{~mL}$ water was used solvent and structure directing molecules. The slurries were heated either in Teflon lined steel autoclaves or in thin glass tubes placed in the steel autoclaves between 110 and $140{ }^{\circ} \mathrm{C}$ for varying reaction times. After the reaction the autoclaves were cooled to room temperature and the reaction products were filtered off and washed with water and ethanol. Both compounds are stable on air for a long time. $\left[\mathrm{Co}(\text { dien })_{2}\right]\left[\mathrm{Co}(\text { tren }) \mathrm{SbS}_{4}\right]_{2} \cdot 0.5 \mathrm{H}_{2} \mathrm{O}$ was obtained at $110{ }^{\circ} \mathrm{C}$ as orange needles (yield approx. $50 \%$ based on $\mathrm{Co}, \mathrm{Sb}$, and $\mathrm{S}$ ) grown on not reacted starting material. $\left\{[\mathrm{Co} \text { (tren) }]_{2}\left[\mathrm{CoSb}_{2} \mathrm{~S}_{6}\right]\right\} \cdot \mathrm{H}_{2} \mathrm{O}$ crystallized as green needles (yield: $44 \%$ based on $\mathrm{Co}, \mathrm{Sb}$, and $\mathrm{S}$ ) at temperatures above $110^{\circ} \mathrm{C}$.

For chemical analysis and X-ray powder diffractometry the crystals were manually separated.

CHNS analysis: compound 1: C 19.95, H 5.57, N 15.79, S $20.81 \%$. calc.: C 20.31, H 5.30, N 16.38, S $21.29 \%$;; compound 2: C 15.25, H 4.25, N 11.26, S $19.25 \%$. calc.: C 15.61, H 4.15, N 12.14, S $20.38 \%$.

\section{Crystal structure determination}

The data were measured using an imaging plate diffraction system

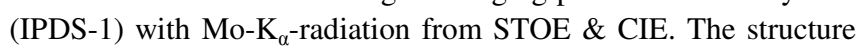
solution was performed with direct methods using SHELXS-97 and structure refinement was performed against $F^{2}$ using SHELXL-97 [64, 65]. A numerical absorption correction was applied using X-Red and X-Shape. All non-hydrogen atoms were refined with anisotropic displacement parameters. All $\mathrm{C}-\mathrm{H}$ and most of the $\mathrm{N}-\mathrm{H}$ hydrogen atoms were positioned with idealized geometry and were refined with fixed isotropic displacement parameters using a riding model. The $\mathrm{O}-\mathrm{H} \mathrm{H}$ atoms of the water 
molecule in both compounds and the $\mathrm{N}-\mathrm{H} \mathrm{H}$ atom in compound 1 were located in difference maps, their bond lengths set to ideal values and finally they were refined using a riding model. In 1 three carbon atoms of the tren molecule are disordered and were refined using a split model. Details of the structure determination are given in Table 1.

CCDC- 733932 (1) and CCDC-733933 (2) contain the supplementary crystallographic data for this paper. These data can be obtained free of charge from the Cambridge Crystallographic Data Centre via www.ccdc.cam.uk/data_request.cif.

\section{Acknowledgments}

The authors thank the State of Schleswig-Holstein and the Fonds der Chemischen Industrie (FCI) for financial support.

[1] R.J.E. Lees, A.V. Powell, D.J. Watkin, A.M. Chippindale, Acta Crystallogr. 2007, C63, m27.

[2] J.B. Parise, Science 1991, 251, 293.

[3] X. Wang, F. Liebau, J. Solid State Chem. 1994, 111385.

[4] X. Wang, Eur. J. Solid State Inorg. Chem. 1995, 32, 303.

[5] Y. Ko, K. Tan, J.B. Parise, A. Darovsky, Chem. Mater. 1996, 8, 493.

[6] K.Tan, Y. Ko, J.B. Parise, Acta Crystallogr. 1994, C50, 1439.

[7] J.B. Parise, Y. Ko, Chem. Mater. 1992, 4, 1446.

[8] K. Tan, Y. Ko, J.B. Parise, J.-H. Park, A. Darovsky, Chem. Mater. 1996, 8, 2510.

[9] X. Wang, A.J. Jacobson, F. Liebau J. Solid State Chem. 1998, $140,387$.

[10] M. Zhang, T.L. Sheng, X.H. Huang, R.B. Fu, X. Wang, S.M. Hu, S.C. Xiang, X.T. Wu, Eur. J. Inorg. Chem. 2007, 1606.

[11] M. Schur, A. Gruhl, C. Näther, I. Jess, W. Bensch, Z. Naturforsch. 1999, 54b, 1524.

[12] A. Puls, M. Schaefer, C. Näther, W. Bensch, A. V. Powell, S. Boissière, A.M. Chippindale, J. Solid State Chem. 2005, 178, 1171.

[13] A. Puls, C. Näther, W. Bensch, Acta Crystallogr. 2006, E62, m674.

[14] A. Puls, C. Näther, R. Kiebach, W. Bensch, Solid State Sci. 2006, $8,1085$.

[15] A. Puls, C. Näther, W. Bensch, Acta Crystallogr. 2006, E62, $\mathrm{m} 1045$.

[16] L. Engelke, C. Näther, W. Bensch, Eur. J. Inorg. Chem. 2002, 2936.

[17] V. Spetzler, R. Kiebach, C. Näther, W. Bensch, Z. Anorg. Allg. Chem. 2004, 630, 2398.

[18] V. Spetzler, C. Näther, W. Bensch, Z. Naturforsch. 2006, 61b, 715.

[19] R. Kiebach, C. Näther, W. Bensch, Z. Naturforsch. 2004, 59b, 1314.

[20] R. Kiebach, A. Griebe, C. Näther, W. Bensch, Solid State Sci. 2006, 8,541 .

[21] R. Kiebach, C. Näther, C. P. Sebastian, B. D. Mosel, R. Pöttgen, W. Bensch, J. Solid State Chem. 2006, 179, 3082.

[22] H. Rijnberk, C. Näther, M.Schur, I. Jeß, W. Bensch, Acta Crystallogr. 1998, C54, 920.

[23] H. Rijnberk, C. Näther, W. Bensch, Monatsh. Chem. 2000, $131,721$.
[24] A.V. Powell, S. Boissiere, A.M. Chippindale, Chem. Mater. 2000, 12182 .

[25] R.J.E. Lees, A.V. Powell, A.M. Chippindale, J. Phys. Chem. Solids 2007, 681215.

[26] H.-O. Stephan, M.G. Kanatzidis, Inorg. Chem. 1997, 36, 6050.

[27] P. Vaqueiro, A.M. Chippindale, A.V. Powell, Inorg. Chem. 2004, 43, 7963.

[28] D.-X. Jia, Y. Zhang, J. Dai, Q.-Y. Zhu, X.-M. Gu, J. Solid State Chem. 2004, 177, 2477.

[29] A.V. Powell, R.J.E. Lees, A.M. Chippindale, Inorg. Chem. 2006, 45,4261 .

[30] R. Stähler, C. Näther, W. Bensch, Acta Crystallogr. 2001, C57, 26.

[31] W. Bensch, C. Näther, R. Stähler, Chem. Commun. 2001, 477.

[32] R. Stähler, C. Näther, W. Bensch, Eur. J. Inorg. Chem. 2001, 1835.

[33] R. Stähler, B.-D. Mosel, H. Eckert, W. Bensch, Angew. Chem. 2002, 114, 4671; Angew. Chem. Int. Ed. 2002, 41, 4487.

[34] R. Stähler, C. Näther, W. Bensch, J. Solid State Chem. 2003, 174, 264.

[35] R. Stähler, W. Bensch, Z. Anorg. Allg. Chem. 2002, 628, 1657.

[36] R. Kiebach, F. Studt, C. Näther, W. Bensch, Eur. J. Inorg. Chem. 2004, 2553.

[37] A. V. Powell, R. J. E. Lees, A. M. Chippindale, J. Phys. Chem. Solids 2008, 69, 1000.

[38] J. Zhou, G.-Q. Bian, Y. Zhang, J. Dai, N. Cheng, Z. Anorg. Allg. Chem. 2007, 633, 2701.

[39] A.V. Powell, S. Boissiere, A.M. Chippindale, J. Chem. Soc., Dalton. Trans. 2000, 4192.

[40] A.V. Powell, R. Paniagua, P. Vaqueiro, A.M. Chippindale, Chem. Mater. 2002, 14, 1220.

[41]P. Vaqueiro, A.M. Chippindale, A.R. Cowley, A.V. Powell Inorg. Chem. 2003, 42, 7846.

[42] A.V. Powell, J. Thun, A.M. Chippindale, J. Solid State Chem. 2005, $178,3414$.

[42] V. Spetzler, C. Näther, W. Bensch, Inorg. Chem. 2005, 44, 5805.

[44] V. Spetzler, C. Näther, W. Bensch, J. Solid State Chem. 2006, $179,3541$.

[45] V. Spetzler, H. Rijnberk, C. Näther, W. Bensch, Z. Anorg. Allg. Chem. 2004, 630, 142.

[46] W. Bensch, M. Schur, Eur. J. Solid State Inorg. Chem. 1996, $33,1149$.

[47] W. Bensch, M. Schur, Z. Naturforsch. 1997, 52b, 405.

[48] M. Schur, H. Rijnberk, C. Näther, W. Bensch, Polyhedron 1998, 18, 101.

[49] M. Schur, C. Näther, W. Bensch, Z. Naturforsch. 2001, 56b, 79.

[50] M. Schur, W. Bensch, Z. Naturforsch. 2002, 57b, 1.

[51] L. Engelke, R. Stähler, M. Schur, C. Näther, W. Bensch, R. Pöttgen, M. H. Möller, Z. Naturforsch. 2004, 59b, 869.

[52] A. Puls, C. Näther, W. Bensch, Z. Anorg. Allg. Chem. 2006, $632,1239$.

[53] R. Stähler, W. Bensch, Z. Anorg. Allg. Chem. 2002, 628, 1657.

[54] R. Stähler, W. Bensch, J. Chem. Soc., Dalton Trans. 2001, 2518.

[55] R. Stähler, W. Bensch, Eur. J. Inorg. Chem. 2001, 3073.

[56] M. Schaefer, R. Stähler, W.-R. Kiebach, C. Näther, W. Bensch, Z. Anorg. Allg. Chem. 2004, 630, 1816. 
[57] M. Schaefer, C. Näther, W. Bensch, Monatsh. Chem. 2004, 135, 461.

[58] M. Schaefer, C. Näther, N. Lehnert, W. Bensch, Inorg. Chem. 2004, 43, 2914.

[59] M. Schaefer, D. Kurowski, A. Pfitzner, C. Näther, Z. Rejai, K. Möller, N. Ziegler, W. Bensch, Inorg. Chem. 2006, 45, 3726.

[60] M. Schaefer, L. Engelke, C. Näther, W. Bensch, Z. Anorg. Allg. Chem. 2003, 629, 1912.

[61] M. Schaefer, C. Näther, W. Bensch, Solid State Sci. 2003, 5, 1135.

[62] R. Kiebach, W. Bensch, R.-D. Hoffmann, R. Pöttgen, Z. Anorg. Allg. Chem. 2003, 629, 532.

[63] L. Engelke, C. Näther, P. Eisner, W. Bensch, Z. Anorg. Allg. Chem. 2008, 634, 2959.

[64] G. M. Sheldrick, SHELXS-97, University of Göttingen (1997).

[65] G. M. Sheldrick, SHELXL-97, University of Göttingen (1997).

Received: ((will be filled in by the editorial staff)) Published online: ((will be filled in by the editorial staff)) 
5

6
7

8

9

10

11

12

13

14

15

16

17

18

19

21

22

23

24

25

26

27

29

30

31

32

33

34

35

36

37

38

39

40

41

42

43

44

45

46

47

48

49

50

51

52

53

54

55

56

57

58

59 


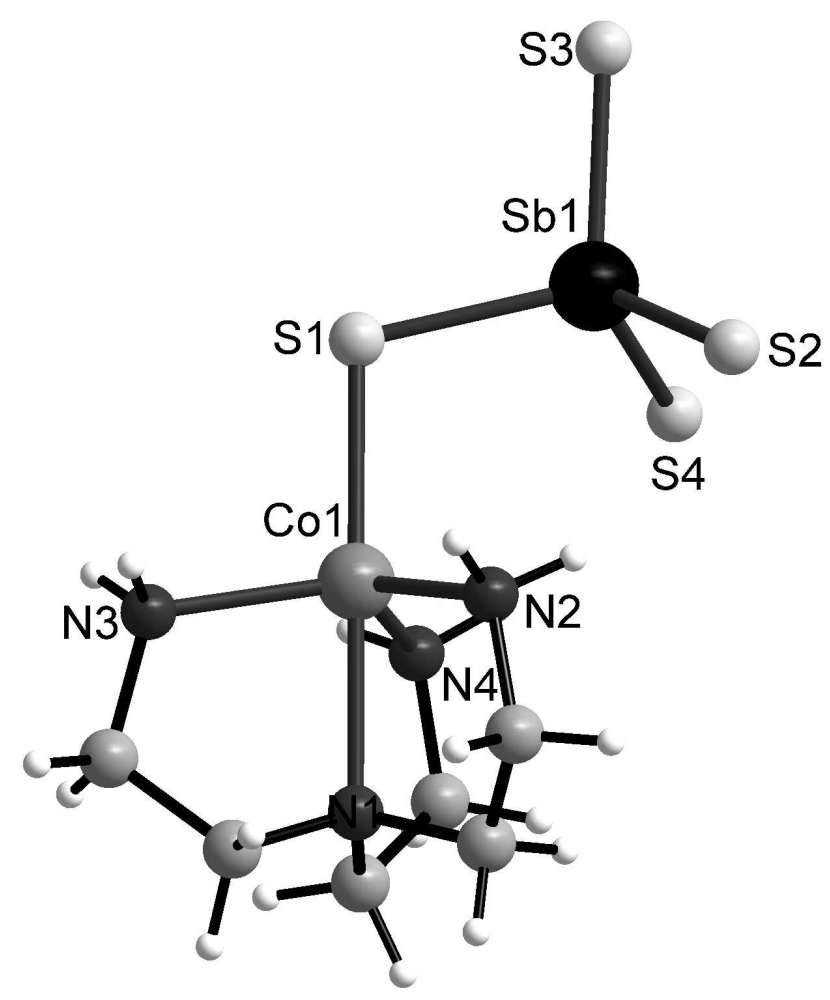

$1058 \times 846 \mathrm{~mm}(96 \times 96 \mathrm{DPI})$ 


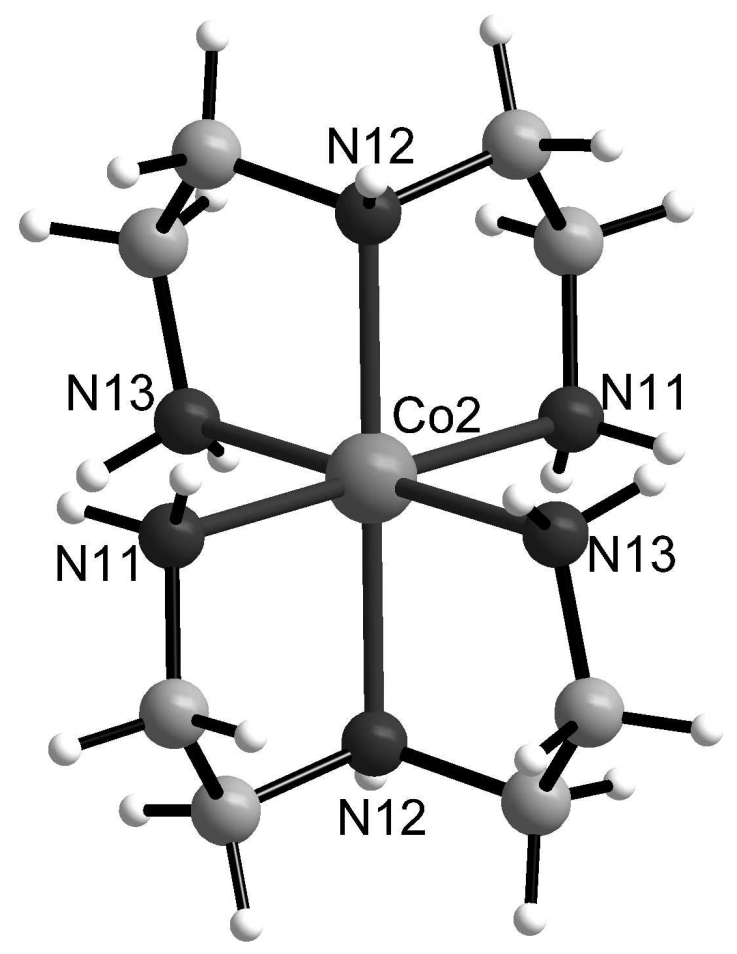

$1058 \times 846 \mathrm{~mm}(96 \times 96 \mathrm{DPI})$ 


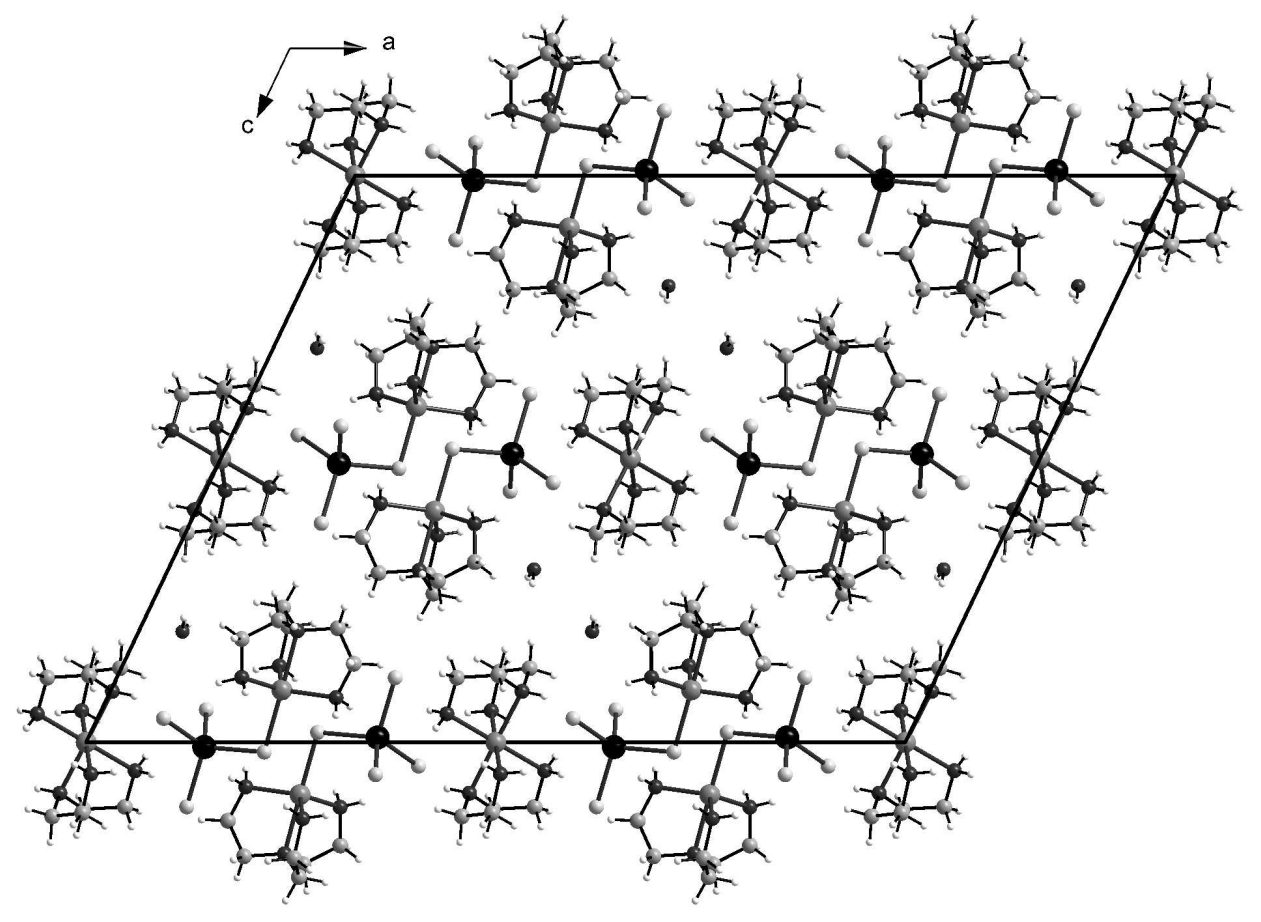

$1058 \times 846 \mathrm{~mm}(96 \times 96$ DPI $)$ 


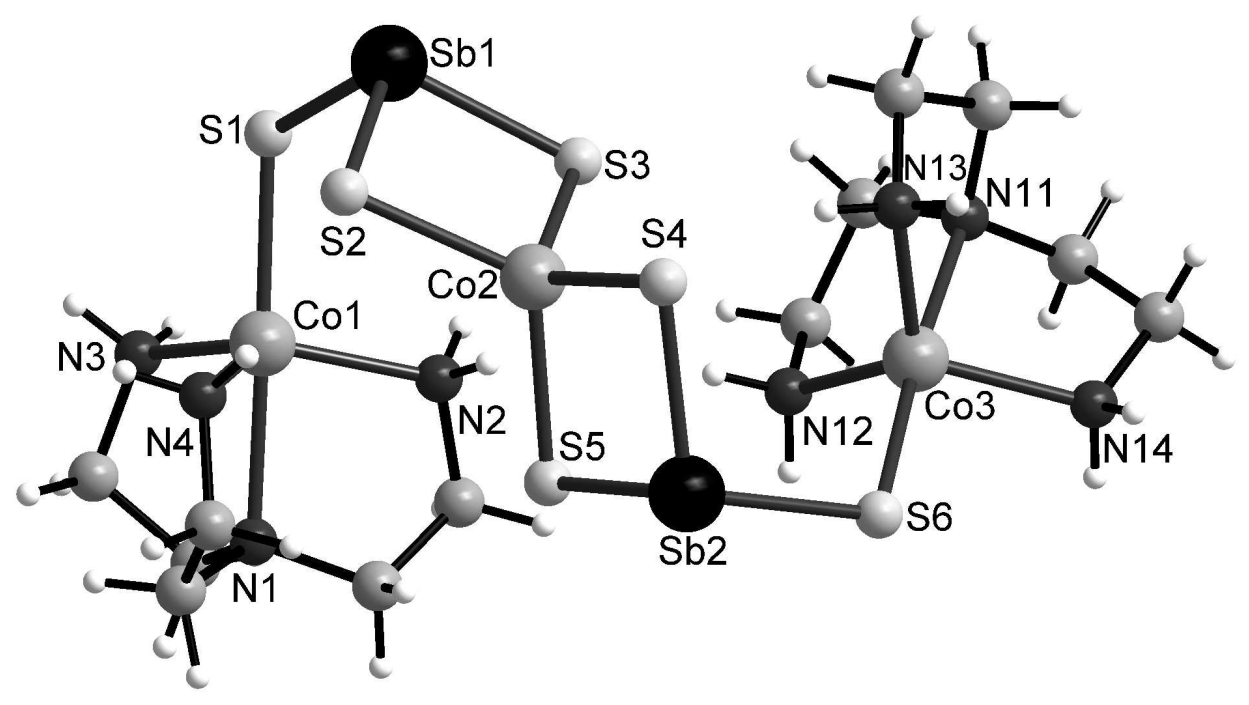

$1058 \times 846 \mathrm{~mm}(96 \times 96 \mathrm{DPI})$ 


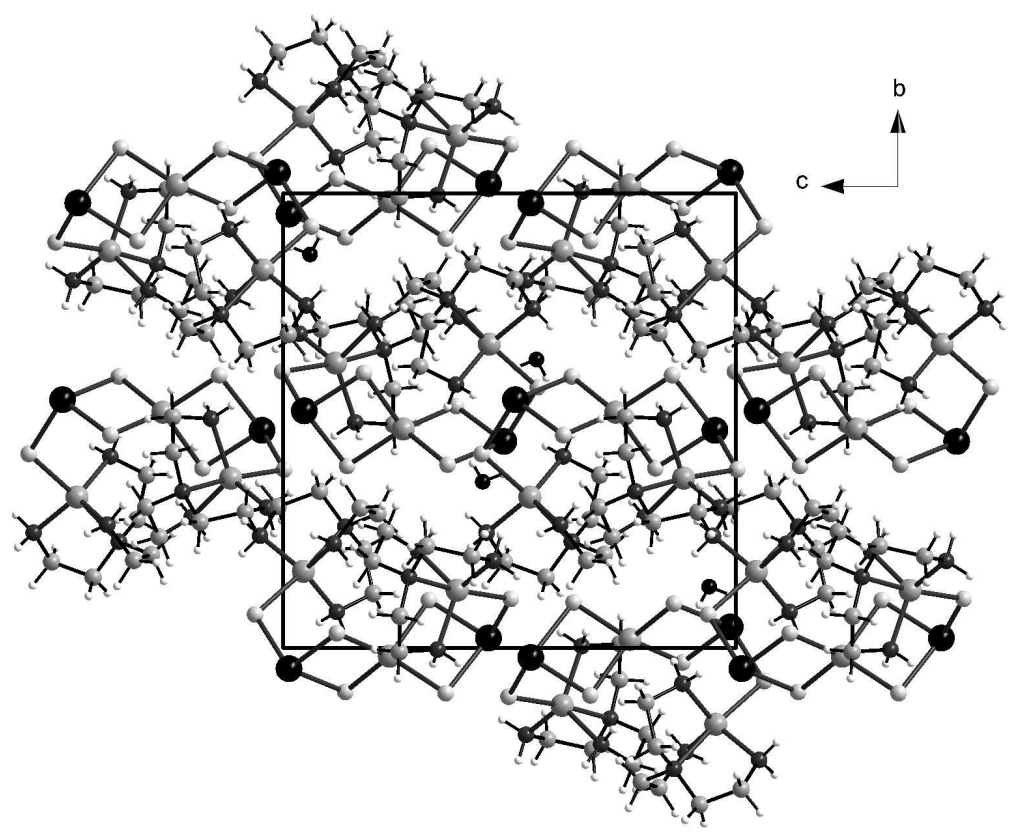

$1058 \times 846 \mathrm{~mm}(96 \times 96$ DPI) 